\title{
sciendo \\ The role of the EFQM model in precepting quality in Polish enterprises
}

doi:10.2478/mape-2019-0040

Date of submission to the Editor: 04/2018

Date of acceptance by the Editor: 07/2018

MAPE 2019, volume 2, issue 1, pp. 399-406

Joanna Rosak-Szyrocka

ORCID ID: 0000-0002-5548-6787

Czestochowa University of Technology, Poland

Marek Roszak

ORCID ID: 0000-0002-4035-8360

Silesian University of Technology, Poland

\section{INTRODUCTION}

Organizational excellence models are designed to strengthen the potential of companies, create the value added, and finally achieve planned results. Depending on the turbulent environment in which companies operate, different concepts and management models are used, including: the Deming model, M. Baldrig's model, EFQM model, or others, individually adapted to the nature, specificity and culture of the organization. Economic situation, in which Polish enterprises found themselves in the early nineties, it required the development of a new vision, strategy and policy as well as a comprehensive reconstruction of management systems. A company striving to achieve market success should systematically review and measure the most important areas of its operations, verify and improve them (Simpson, 2016, Choshin et al., 2017). In literature (Szczepańska, 2012, Molenda, 2012, Skrzypek, 2010, Gerolamo MC et al., 2014) emphasizes the importance of sustainable quality, which it can only be achieved if we concentrate on the most important organizational values. The aim of the research is to determine the degree of maturity of Polish enterprises applying for the Quality of the Year certificate based on the EFQM excellence model. So far, the issue of the analysis of cultural conditions of organizations in the area of the awareness of the quality of Polish enterprises based on the EFQM model in the aspect of the Quality of the Year certificate has not been the subject of broader, comprehensive scientific considerations. The research covered a group of 49 enterprises located in various regions of Poland. On the basis of literature research and analysis of the activities of selected enterprises, the following hypothesis was formulated: using generally known management models, we can determine the factors determining its maturity and awareness in terms of quality, as well as the use of modern techniques. The research was conducted on the basis of a questionnaire (CAWI - Computer Assisted Web Interview), which is the basis for applying for the Quality of the Year certificate.

\footnotetext{
* joanna.rosak-szyrocka@pcz.pl
} 


\section{EFQM MODEL}

Among the solutions aimed at implementing the principle of continuous improvement of the organization, the EFQM excellence model deserves particular attention (Anastasiadou, 2015). The EFQM model combines all elements of the management system in a logical whole showing the strength of the organization and the possibilities of its development. The Business Excellence Model, and since 1999 as the EFQM Excellence Model (EFQM Excellence Model) is the foundation of the European Excellence Excellence Award. EFQM is a comprehensive and advanced tool for organizational improvement, based on the principles of comprehensive quality management (TQM) - a modern concept of a comprehensive, collective effort oriented towards continuous improvement of the organization in all aspects, spheres and effects of its operations. The last update took place in 2012 (Rogala, 2013). Currently, the EFQM model is a simplified and transparent picture of reality (Skrzypek, 2014, Kacała, et al., 2012). EFQM is used by around 30,000 organizations in Europe and around the world.

The European Quality Award was constructed on the basis of the EFQM model used by tens of thousands of European organizations to improve the management system. In the EFQM model, the basic tool for data collection are special questionnaires to help organize in a systematic way the knowledge about the organization and its operation. Self-assessment in the enterprise allows (Wolniak, 2010):

- help the organization to identify its current position and define future directions and development priorities,

- providing a method of continuous monitoring of the organization's functioning,

- ensure that all members of the organization have the same picture of strengths and weaknesses,

- defining priorities for organizational improvement,

- ensure that the organization does not undertake an excessive number of improvement activities at the same time.

The basic feature of the Model of Excellence is its universality, i.e. the possibility of its use in any organization regardless of type, size, industry or sector of economy. The goal of EFQM is to strengthen the position of industry and European trade by strengthening the role of quality in corporate strategies. The EFQM mission, on the other hand, is (Bazanowski, 2004, Henrykowski, 2003):

- stimulating European companies to improve their activities and helping in these activities, the effect is to achieve full customer satisfaction,

- supporting European managers in accelerating the process of implementing TQM as a decisive factor in gaining a competitive advantage in the market.

A representative office of the European Foundation for Quality Management (EFQM) was established in Poland - the National Partner Organization (NPO) - by three leading and closely cooperating national organizations: the Polish Center for Testing and Certification (PCBC SA), the National Chamber of Commerce (KIG), and Umbrella - Association of Consultants (Henrykowski, 2003). NPO's mission is to stimulate and support Polish organizations in their pursuit of excellence. The basic tasks of the NPO include: awarding EFQM European awards to national organizations, distribution of the Polish version of EFQM materials, licensing access to the Excellence One online knowledge exchange platform, promotion and 
dissemination of the EFQM Excellence Model, close cooperation with EFQM, providing services in the EFQM Model (Rogala, 2013, Henrykowski, 2003). Table 1 shows the evolution of the EFQM model in individual years.

Table 1.

Evolution of the EFQM excellence model

\begin{tabular}{|c|c|}
\hline 1991 & - Introduction of the EFQM model \\
\hline 1999 & $\begin{array}{ll}- & \text { Introduction } 8 \text { quality management principles } \\
- & \text { Introduction the RADAR model } \\
- & \text { Renaming the selected criteria }\end{array}$ \\
\hline 2003 & $\begin{array}{l}\text { - Changing the name of the principle Public responsibility on corporate social } \\
\text { responsibility } \\
\text { - Introducing significant changes in the RADAR model } \\
\text { - Introduction different versions of the model for individual sectors }\end{array}$ \\
\hline 2010 & $\begin{array}{l}\text { - Focus on future results (risk management, innovation) } \\
\text { - Integration of the rules and criteria of the model } \\
\text { - One version of the model for all sectors } \\
-\quad \text { Changing the name of the criterion Processes to the name Processes, products and } \\
\text { services } \\
\text { - Change in the number of points awarded under the criteria }\end{array}$ \\
\hline 2013 & $\begin{array}{l}\text { - Focus on the flexibility and agility of the organization } \\
\text { - Simplification of vocabulary } \\
\text { - } \quad \text { Changing the name of the criterion Key benefits to the name Business benefits } \\
\text { - } \quad \text { Changes in the RADAR model }\end{array}$ \\
\hline
\end{tabular}

Source: own study based on: (Rogala, 2013).

The changes introduced by EFQM in 2012 do not have a revolutionary character, they do not significantly affect the perception of the EFQM model and the way companies conduct self-assessment. As emphasized (Rogala, 2013), the changes introduced result from the experience gained on the one hand, and from the necessity of adapting to the environment on the other.

\section{IMPROVEMENT OF THE ORGANIZATION IN THE ASPECT OF SELF- ASSESSMENT}

In the era of globalization and the Internet, the customer can decide easily and simply about choosing a company, evaluating the quality of products, comparing reliability and the price of products/services. For an organization to succeed, it is no longer enough that it will be good on the market, but it should improve in every area and constantly strive for perfection (Henrykowski, 2003). Organizations operating in business are constantly looking for new tools, methods and systems in order to maximize profits and strengthen their competitive advantage. Continuous improvement is one of the conditions for meeting customer requirements (Ejdys, et al. 2012).

Improving management in the organization is an endless process that leads to an increase in the overall efficiency of the organization (Beer, et al., 2000). The organization of the questionnaires independently diagnoses, improves, corrects and prevents (Zymonik, 2009). Self-evaluation, in line with such values as self-control and empowerment, alleviates the employees' resistance to the assessment process and meets their approval. Self-assessment helps to determine the level of organization's maturity, advancement in the use of modern techniques and achieved results. It allows you to get an idea of how far the organization has progressed through the 
implementation of the concept of management through quality and what it must do to achieve success (Recha, 2009). Many authors (Rusjan, 2005, Sampaio et al 2012, Asif et al., 2014) claim that the EFQM model proposes several different approaches on the road to excellence. In their view, organizations can develop best practices in a coherent way using the model.

The authors (He, et al., 2011, Karimi, et al., 2014) believe that perfect management of the potential criterion leads to excellence in results. The EFQM model is a model to be followed by many organizations (Dahlgaard, et al. 2013, Escrig, et al., 2015).

As results from Polish research (Haffer, 2011), enterprises use self-assessment, first and foremost to measure the success achieved and determine future implementations, discover and share within the organization best practices, delivering visions and the pattern of perfection to follow. The reference of market success, which can be understood as the acquisition of a large (or even dominant) market share by a business organization within a given period of time, is a strong motivation to undertake actions aimed at achieving it (Leman-Tomaszewska, et al., 2012). As emphasized by Godzwon Z. (2014), the self-assessment method is a contribution to determining the strengths and weaknesses of pro-quality activities. The results of the analysis of research carried out by an international team on EFQM award winners for excellence and national quality awards pointed to the accelerated development of the awarded business entities in relation to the representatives of the control group who did not implement the EFQM model (Boulter, 2005).

The results obtained in the studies (Heras, 2010) and external evaluations of nearly three hundred Spanish and Basque companies in 1998-2007 showed that the most important factor prompting the implementation of the EFQM model of excellence was the improvement of organization and planning in companies. Analysis of research carried out by many authors (Kacała, et al., 2012, Godzwon, 2007, LemanTomaszewska, and in. 2012, Szczepańska, 2012, Anastasiadou, et al. 2015, Ahmada, et al., 2016), both domestic and foreign in the EFQM model, showed that this factor was dominant (around $60 \%$ of enterprises considered it to be key) over improving the image, improving the quality of products and services.

\section{SURVEY RESEARCH}

In order to find out where in the direction of excellence there are enterprises operating on the Polish market and what is the level of maturity of the organization, a survey was conducted. The aim of the study was to collect empirical materials on the results of analysis of 9 areas included in the EFQM excellence model (1. Leadership 2. Vision, strategy, policy 3. Human resources management 4. Resource management 5. Process management 6 . Customer satisfaction. 7. Satisfaction of employees 8. Cooperation with the environment 9 . Achievements of the company in relation to the assumed goals).

The survey was conducted in 2013, 2014 and 2015. Research facilities are large (enterprises employ more than 250 employees), located in various regions of Poland. In order to obtain the Quality of the Year certificate, the company had to maintain a minimum of $56 \%$ of points in the scope of self-assessment.

The survey was completed by 70 companies, however, a group of 49 entities were selected for further research, which met the assumptions of the adopted research plan. The representative sample was 49 large enterprises, both production, service 
and production and service. 11 research facilities did not meet the requirements related to the procedure of obtaining the Quality of the Year certificate (no certificate of non-resignation from Social Security and Tax Office, incorrect or incomplete completion of the survey).

Figure 1 presents the results of research based on which the result of the EFQM model can be seen in individual research objects in 2013. The analysis of the data presented in Figure 1 allows to conclude that as many as eight research objects did not achieve the minimum as a result of self-assessment, i.e. $56 \%$ per $100 \%$ possible to obtain. Data analysis allows us to state that improving quality in an enterprise is a very difficult and time-consuming process, as evidenced by the fact that out of 49 enterprises, only 3 obtained the value of $80 \%$ and above. Authors of research emphasize that self-evaluation is very important for improving services and the competitiveness of organizations in the global market. It was found that companies applying for the Quality of the Year certificate enables their performance to be assessed in terms of achieving a high level of performance.

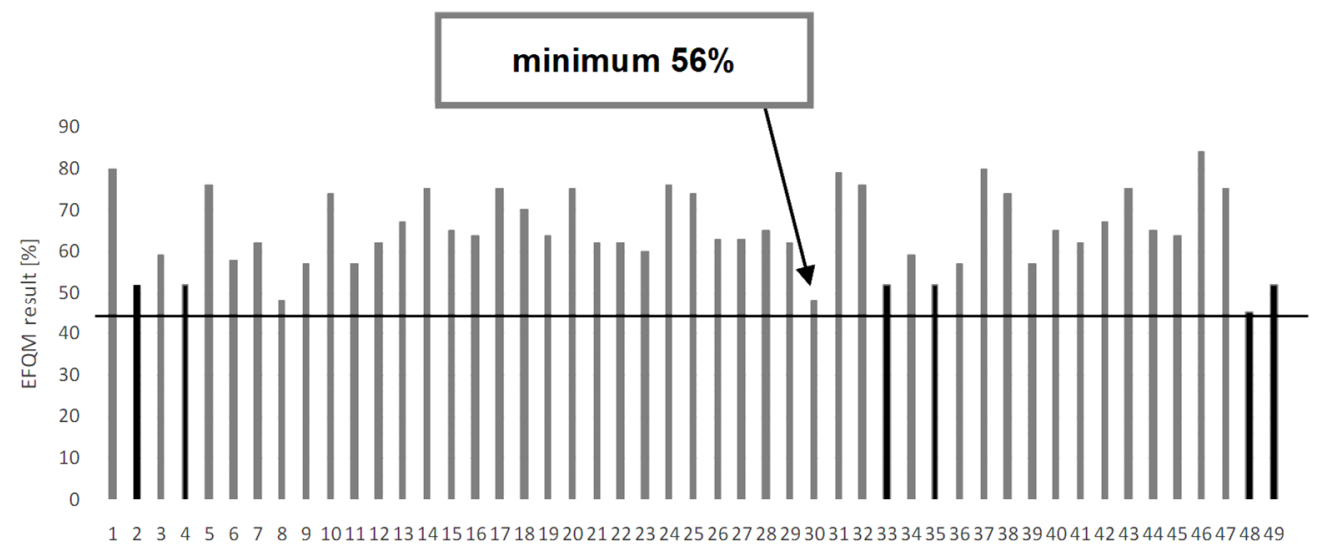

Number of research object

Fig. 1. The result of the self-assessment based on the EFQM model in research facilities

\section{RESULTS}

The conducted research showed that Polish enterprises applying for the Quality of the Year certificate are aware of the quality and its impact on the company's performance. Getting the Quality of the Year certificate creates added value, allows managers to plan improvement processes, helps employees to define and improve processes, and clients helps to assess and qualify suppliers of products/services. Analysis of the results of the EFQM model in organizations showed that many improvement actions in enterprises are failing. This is due to the failure to understand the essence of improvement actions and the lack of a systematic approach to their application. Applying for the Quality of the Year certificate is treated as a direction of improvement of enterprises. In a systemic way, it allows to assess the strengths and weaknesses of the organization, giving a real chance to apply the right ways to improve the efficiency and effectiveness of the processes. Self-assessment conducted by enterprises reflects the organization's advancement in striving to be the best in providing a given service or in offering a product. It facilitates understanding of the essence of business, helps in measuring the position in evolution to perfection 
and in identifying the existing imperfections (gaps). The success of the Quality of the Year certificate depends on the company's ability to learn and apply benchmarking. Obtaining a certificate allows organizations to perceive themselves as a more and more perfect system, and allows continuous monitoring of improvement activities. It has been found that thanks to the self-assessment carried out within the organization, best practices are shared, the company's vision and the pattern of excellence to follow are provided.

\section{DISCUSSION}

EFQM is an excellent tool to help your organization achieve success. The combination of the experience of the organization and crew management as well as the international guidelines of the perfect organization gives a real opportunity to develop the position of a strong and competitive enterprise. The EFQM model allows you to match up to the best-managed organizations in Europe in a short time. Once this level of excellence has been achieved, they can, by obtaining distinctions and EFQM awards, demonstrate in them the undisputed way that they belong to the best European leaders (Rogala, et al., 2013). The presented analysis allows to state that the enterprises that applied for for the Quality of the Year certificate, and at the same time they achieved a high self-assessment result, show accelerated development because thanks to the EFQM model they know what areas need improvement. Based on the presented evidence and analysis, it can be concluded that the scientific hypothesis: Using generally known management models, we can determine the factors determining its maturity and awareness in terms of quality, as well as the use of modern techniques has been proven.

\section{REFEENCES}

Ahmada, R., Jankala, R. and Jankalova, M. (2016). The application of the EFQM excellence model by the evaluation of corporate social responsibility activities of companies. Procedia Economics and Finance, 39, pp. 660-667.

Anastasiadou, S.D., Zirinogloub, P.A. (2015). EFQM dimensions in Greek Primary Education System. Procedia Economics and Finance, 33, pp. 411-431.

Asif, M., Gouthier, M.H. (2014). What service excellence can learn from business excellence models. Total Quality Management and Business Excellence, 25(5-6), pp. 511-531.

Bazanowski, W., Błaszczyk, F. (2004). Pojęcie i koncepcje jakości. Antidotum, 4, pp. 34.

Beer, M., Nohria, N. (2000). Breaking the Code of Change. Harvard Business Review, 78(3), pp. 133-141.

Boulter, L. (2005). Report on EFQM and BQF funded study into the impact of the effective implementation of organizational excellence strategies on key performance results. Centre of Quality Excellence the University of Leicester.

Choshin, M., Ghaffari A. (2017). An investigation of the impact of effective factors on the success of e-commerce in small - and medium-sized companies. Computers in Human Behavior, 66(1), pp. 67-74.

Dahlgaard, J.J., Chen, C.K., Jang, J.Y., Banegas, L.A., Dahlgaard-Park, S.M. (2013). Business excellence models: limitations, reflections and further development. Total Quality Management and Business Excellence, 24(5-6), pp. 519-538.

Ejdys, J., Kobylińska, U., Lulewicz-Sas, A. (2012). Zintegrowane systemy zarządzania jakością środowiskiem i bezpieczeństwem pracy. Białystok: Oficyna Wydawnicza Politechniki Białostockiej, pp. 229.

Escrig, A. B., Lilian, M. de Menezes. (2015). What characterizes leading companies within business excellence models? An analysis of "EFQM Recognized for Excellence" recipients in Spain. Production Economics (169), pp. 362-375. 
Gerolamo, M.C., Poltronieri, C.F., Yamada, T.T. and Cintra A.L.B. (2014). How do Brazilian companies do it? Quality Management, Procedia - Social and Behaviorak Sciences, 3rd International Conference on Educational Research, CY-ICER 2014, 30 January-1 February 2014, Lefkosa, North Cyprus, pp. 995-1000.

Godzwon, Z. (2007). Samoocena jako narzędzie zarządzania jakością usługi edukacyjnej w szkole wyższej. Problemy Jakości, 07, pp. 40-45.

Haffer, R. (2011). Samoocena i pomiar wyników działalności w systemach zarządzania przedsiębiorstw. W poszukiwaniu doskonałości biznesowej. Toruń: Wydawnictwo Naukowe Uniwersytetu Mikołaja Kopernika, s. 582.

He, Z., Hill, J., Wang, P., Yue, G. (2011). Validation of the theoretical model underlying the Baldrige criteria: evidence from China. Total Quality Management, 22(2), pp. 243-263.

Henrykowski, W. (2003). Krajowa narodowa jednostka partnerska EFQM. Problemy Jakości, 4, pp. 43-45.

Heras, I. (2010). ISO 9001 Vs. EFQM: A comparative analysis based on external independent data. 4th International Conference on Industrial Engineering and Industrial Management, Donostia - San Sebastián, September 8th-10th, pp. 1575-1582.

Kacała, J., Kołaczyk, E. (2012). Efektywność wdrażania modelu doskonałości EFQM. In: A., Wierzbic, M., Wąsowicz, ed., Trendy transformacji modelu organizacyjnego przedsiębiorstwa. Prace Naukowe UE, 274, pp. 157-166.

Kacała, J., Wierzbic, A. (2015). Od systemów znormalizowanych do doskonałości biznesowej. Management Forum, 3(4), pp. 28-32.

Karimi, A., Safari, H., Hashemi, S.H., Kalantar, P. (2014). A study of the Baldrige award framework using the applicant scoring data. Total Quality Management Business Excellence, 25(5-6), pp. 461-477.

Leman-Tomaszewska, M., Latowska, K., Kłos, Z. and Koper, K. (2012). Postrzeganie stosowania modelu doskonałości EFQM w kontekście sukcesu rynkowego. Zarządzanie i Finanse, 10(3) cz. 1, pp. 157-169.

Molenda, M. (2012). Znaczenie wartości organizacyjnych w rozwoju kultury jakości. Zeszyty Naukowe Politechniki Śląskiej. Seria: Organizacja i Zarządzanie, 63a(1891), pp. 209219.

Recha, M. (2009). Samoocena organizacji. Problemy Jakości, 8, pp. 45-49.

Rogala, P. (2013). Model Doskonałości EFQM 2013 - ewolucja a nie rewolucja. Problemy Jakości, 11, pp. 4-6.

Rusjan, B. (2005). Usefulness of the EFQM Excellence model: theoretical explanation of some conceptual and methodological issues. Total Quality Management, 16(6), pp. 363-380.

Sampaio, P., Saraiva, P., Monteiro, P. (2012). A comparison and usage overview of business excellence models. TQM, 24(2), pp. 181-200.

Simpson, C.H. (2016). Competition for foundation patronage and the differential effects of prestige on the grant market success of social movement organisations. Social Networks, 46(7), pp. 29-43.

Skrzypek, A. (2014). Jakościowe aspekty doskonalenia zarządzania organizacją. Zeszyty Naukowe Uniwersytetu Przyrodniczo-Humanistycznego w Siedlcach Nr 100, seria Administracja i Zarządzanie, 2.1, pp. 131-146.

Skrzypek, E. (2010). Doskonalenie jakości jako szansa na sukces organizacji. Współczesne Zarządzanie, 3, pp. 42-50.

Szczepańska, K. (2012). Doskonalenie i samoocena w zarządzaniu jakością w przedsiębiorstwie. Problemy Zarządzania, 10(2 (37)), pp. 9-27.

Wolniak, R. (2010). Nowy model doskonałości EFQM. Problemy Jakości, 09, pp. 4-8.

Zymonik, J. (2009). Polska Nagroda Jakości w świetle 
Abstract: The purpose of the paper is to determine the degree of Polish companies' maturity applying for Quality of the Year certification based on the EFQM excellence model. The study was conducted using a questionnaire (CAWI - computer assisted web interview). Company to get certified Quality of the Year had to get in the field of self-assessment carried out by the EFQM model at least $56 \%$. Results and its analysis showed that among the 49 analyzed large companies seeking Quality of the Year certification only 3 achieved a value of $80 \%$ and above. Among the 10 companies selected for analysis only 3 has taken improvement actions. Based on the study carried out, the authors demonstrated that the analyzed companies that have been certified Quality of the Year are mature and conscious of quality, continuously improve, and apply modern techniques (traditional quality management tools, new quality management tools, quality management methods). The factors that determine the maturity and the awareness of the company in terms of quality are the elements included in the EFQM model (1. Leadership. 2. Vision, strategy, policy. 3. Human resources management. 4. Resource Management. 5. Process Management. 6. Customer satisfaction. 7. Employee satisfaction. 8. Cooperation with the environment. 9. Achievements companies in relation to the goals), as well as the awareness and the ability to use modern techniques.

Keywords: quality of the Year certificate, EFQM, self-assessment, quality, improvement 